\title{
INVESTIGATION OF SIXTH GRADE STUDENTS' LEVEL OF ACHIEVEMENT ON THE ADVENTURE OF DEMOCRACY UNIT IN SOCIAL STUDIES IN TERMS OF SOME VARIABLES
}

\author{
ALTINCI SINIF ÖĞRENCILERININ SOSYAL BILGILER DERSINDEKI \\ DEMOKRASININ SERÜVENİ ÜNITESINNE YÖNELIKK BAŞARİ DÜZEYLERINIIN BAZİ \\ DEĞİŞKENLER AÇİSINDAN İNCELENMESI
}

\begin{abstract}
İsmail Hakan AKGÜN ${ }^{1}$
Abstract

The objective of this study is to determine the level of fulfilment of five acquisitions aimed to gain the students in the "Adventure of Democracy" unit of "Power, Management and Society" learning area of sixth grade social studies lesson taught in Turkey, in terms of different variables. The number of researches investing the level of fulfilment of Social Studies lesson's acquisitions in Turkey is quite limited, and one of the quantitative research methods, the survey method was used in this study carried out for filling this gap in the literature. The academic success test was used in order to collect the research data, the data obtained were analyzed using the SPSS program. At the end of the research, it was observed that the level of fulfilment of the unit's acquisitions is at intermediate level among students; the level of learning increases with the increase in the level of education of the parents, but this difference is not statistically significant; the academic success of the students living in the city is significantly higher than the students living in the village; and the academic success of the students whose family income level is below $750 \mathrm{TL}$ is significantly lower than the students whose family income is above 750 TL.
\end{abstract}

Key Words: Social Studies Education in Turkey, Democracy Education, Adventure of Democracy

\section{$\ddot{O} \mathbf{z}$}

Bu araştırmanın amacı Türkiye'de okutulmakta olan sosyal bilgiler dersi altıncı sınıf "Güç. Yönetim ve Toplum" öğrenme alanı "Demokrasinin Serüveni" ünitesinde öğrencilere kazandırılması hedeflenen beş kazanımın çeşitli değişkenler açısından öğrencilerde gerçekleşme düzeyini tespit etmektir. Türkiye'de Sosyal Bilgiler dersi kazanımlarının gerçekleşme düzeyinin ne ölçüde olduğuna yönelik araştırma sayısı oldukça az olup literatürdeki bu boşluğu doldurmak amaciyla yapılan bu çalışmada nicel araştırma yöntemlerinden olan tarama modeli kullanılmıştır. Araştırma verilerini toplamak için akademik başarı testi kullanılmış olup elde edilen veriler SPSS programı ile analiz edlmiştir. Araştırma sonucunda; ünite kazanımlarının öğrencilerde gerçekleşme düzeyinin orta düzeyde olduğu, ebeveyn eğitim düzeyi arttıkça öğrenme düzeyinin arttığı ancak bu farkın istatistiksel olarak anlamlı olmadığı görülmüştür. Ayrıca şehirde yaşayan öğrencilerin akademik başarılarının köyde yaşayan öğrencilere göre anlamlı düzeyde yüksek olduğu ve aile gelir düzeyi 750 TL'nin altında olan öğrencilerin akademik başarılarının, aile geliri 750 TL'nin üstünde olan öğrencilere göre anlamlı düzeyde düşük olduğu tespit edilmiştir.

Anahtar Kelimeler: Türkiye’de Sosyal Bilgiler Eğitimi, Demokrasi Eğitimi, Demokrasinin Serüveni.

\footnotetext{
${ }^{1}$ Yrd.Doç.Dr., Adıyaman Üniversitesi Eğitim Fakültesi Sosyal Bilgiler Eğitimi Ana Bilim Dalı, hakanakgun02@gmail.com
} 


\section{INTRODUCTION}

In today's world, there is quite a fast change and development in many areas such as science, technology, politics and democracy; and this affect almost everywhere in the world, either positively or negatively. Each developed or developing state is trying to raise individuals who will be able to adapt these developments and who have internalized the democracy.

Democracy is a concept in Latin comprising of the combination of the words "demos" meaning people, and "kratos" meaning rule (Gunduz and Gunduz, 2007). One of the most popular definitions of democracy is the "Government of the people, by the people, for the people" by Abraham Lincoln (1863), one of the former presidents of the United States of America (Uygun, 2003). In Turkish dictionary, democracy is defined as the "regime based on people's sovereignty, democracy, being a democrat" (TTK, 2009: 495).

The changes in today's world are not always positive. Especially the recent social and political situations in various parts of the world, such as economic interdependence, terror, insensitivity towards politics, growing social divisions threaten the democratic stability. For these reasons, human rights and democratic citizenship education have ranked among the main priorities of the governments recently (Flowers, 2010). For democracy cannot exist without democratic citizens; the power that makes up and maintains the democracy is democratic citizens (Parker, 2009). And raising democratic citizens is only possible with education.

Subjects of citizenship and democracy in Turkey are being tried to gain the students either with individual lessons such as Citizenship and Democracy Education, Human Rights Education, and with an interdisciplinary approach in such lessons as Social Studies, Life Sciences, Turkish, Ataturk's Principles and History of Turkish Revolution, etc. Especially the subjects of citizenship and democracy in social studies lessons taught in the 4th, 5th, 6th and 7 th grades have an important place.

The citizenship education in Turkey aims to transmit the students the necessary knowledge, skills and values to form a democratic society. Raising students who can think critically on issues, express their thoughts, respects other's thoughts, have the culture of living in peace and together, are sensitive towards the society, and can take action for the goodness of the society is also among the objectives of the citizenship education. Individuals raised this way learn the laws, justice, non-discrimination, hence the democracy, while they learn their rights, responsibilities and independence (TTK, 2010).

Naturally, that the democracy subjects are included in the scope of the lessons does not mean that these are definitely learnt by the students. In the literature review made, it was seen that there is scarcely any studies on students' level of learning the acquisitions related to democracy. In this research carried out with the aim of filling this gap in the literature, it was endeavoured to establish the level of fulfilment of the following five acquisitions aimed to gain the students in the "Adventure of Democracy" unit of "Power, Management and Society" learning area sixth grade social studies in Turkey in terms of several variables: 1 . She compares different regimes in terms of the main principles of democracy. 2. She discusses the historical development of the democratic management understanding in different periods and cultures. 3. She defends that everyone should have the right to life, the right to physical integrity, freedom of religion and conscience, and freedom of thought in democratic regimes. 4. She analyzes the development process of human rights based on historical documents. 5 . She interprets the examples on the position of women in Turkish history in terms of the development of human rights. 
In this context, the objective of this study is to determine the level of fulfilment of five acquisitions aimed to gain the students in the "Adventure of Democracy" unit of "Power, Management and Society" learning area of sixth grade social studies lesson taught in Turkey, in terms of different variables. Accordingly, in this research, answer to the question of what extent is students' academic achievement in terms of gender, parental education level, place of residence and family income levels is sought.

\section{METHODOLOGY}

One of the quantitative research methods, the survey model was used in the research. The survey model is a research approach that aims to depict a past or a current situation as it is. In the survey model, the situation, individual or object that is the subject of the research is tried to be defined as it is under its own conditions, and no such an effort is shown to alter or affect them (Karasar, 2007). In this study, students' level of learning the unit of the "Adventure of Democracy" included in the scope of the sixth grade social studies lesson in Turkey was investigated in terms of other variables.

\subsection{Participants}

The universe of the research is comprised of the 6th Grade students in Adiyaman province, who are taught the social studies lesson. And its sample consist of 122 students $(n=122)$ from 3 primary education schools in Adiyaman in total, one of them being a village school, and the other two are schools in the city. Table 1.

Demographic information on the students participating in the research is given in

Table 1: Demographic Information

\begin{tabular}{llcc}
\hline & & Frequency $(\boldsymbol{f})$ & Percentage (\%) \\
Gender & Female & 63 & 51,6 \\
& Male & 59 & 48,4 \\
& Primary school & 70 & 57,4 \\
Maternal & Secondary school & 30 & 24,6 \\
education level & High school & 10 & 8,2 \\
& University & 3 & 2,5 \\
& Illiterate & 9 & 7,4 \\
& Illiterate & 4 & 3,3 \\
Paternal & Primary school & 45 & 36,9 \\
education level & Secondary school & 33 & 27 \\
& High school & 32 & 26,2 \\
Settlement & University & 8 & 6,6 \\
& Village & 45 & 36,9 \\
Income Level of & City & 77 & 63,1 \\
the Family & $\mathbf{0 - 7 5 0}$ & 62 & 50,8 \\
& $\mathbf{7 5 1 - 1 5 0 0}$ & 41 & 33,6 \\
& $\mathbf{1 5 0 1 - 2 5 0 0}$ & 11 & 9 \\
& $\mathbf{2 5 0 0}$ and above & 8 & 6,6 \\
\hline
\end{tabular}


In Table 1, the percentage and frequency values of the information on the gender, maternal-paternal education level, settlement and family income level of the students participating in the research are shown.

\subsection{Means of Data Collection}

As a data collection tool, an achievement test with 40 multiple-choice questions in total (with 1 correct and 3 distractors) consisting of 8 questions for each acquisition was prepared with regard to 5 acquisitions aimed to teach the students with the unit "the Adventure of Democracy" in line with the views of 3 experts and 2 subject teachers. Sixth grade social studies course books adopted by the Ministry of National Education (MEB), various question banks, the internet, relevant sources in the literature and the questions developed by the researcher himself were used when preparing the questions.

The pilot application of the test were carried out with 204 students $(n=204)$ who were taught the subject in 6 schools in total across Adiyaman province. The reliability analysis of the achievement test was carried out using ITEMAN program (Itemand Test Analysis Program) and the Alpha value of the test was found as 0.885 . As a result of the analysis of the pilot application, 5 questions were chosen for each acquisition among the questions with a discrimination index above .30, and a final achievement test of 25 questions was obtained. The item analysis results of the achievement test are shown in Table 2.

Table 2. Item Analysis Results of the Achievement Test

\begin{tabular}{|c|c|c|c|c|c|}
\hline Question No & $\begin{array}{c}\text { Index of } \\
\text { Difficulty }\end{array}$ & $\begin{array}{c}\text { Index of } \\
\text { Discriminati } \\
\text { on }\end{array}$ & Question No & $\begin{array}{c}\text { Index of } \\
\text { Difficulty }\end{array}$ & $\begin{array}{c}\text { Index of } \\
\text { Discriminati } \\
\text { on }\end{array}$ \\
\hline 1 & .54 & .47 & 14 & .46 & .52 \\
\hline 2 & .47 & .47 & 15 & .49 & .60 \\
\hline 3 & .72 & .56 & 16 & .42 & .65 \\
\hline 4 & .56 & .74 & 17 & .44 & .57 \\
\hline 5 & .36 & .37 & 18 & .52 & .69 \\
\hline 6 & .58 & .47 & 19 & .42 & .44 \\
\hline 7 & .45 & .35 & 20 & .60 & .59 \\
\hline 8 & .59 & .72 & 21 & .62 & .64 \\
\hline 9 & .47 & .65 & 22 & .46 & .65 \\
\hline 10 & .62 & .59 & 23 & .49 & .59 \\
\hline 11 & .45 & .56 & 24 & .52 & .49 \\
\hline 12 & .47 & .42 & 25 & .59 & .66 \\
\hline 13 & .67 & .66 & & & \\
\hline
\end{tabular}

When the results of the ITEMAN analysis of the achievement test on Table 2 are examined, it is seen that the indices of difficulty of the items in the test are between .36 and .72. In other words, the test consists of easy and difficult items. The indices of difficulty of the items in the index of difficulty showing the rate of correct answering of the items used in the skill and achievement test where knowledge and skills are measured is expected to be around 0.50 (Buyukozturk et al. 2013: 123). The average item difficulty of the items in the test is 
0.519 , and according to this rate, it can be asserted that this is a useable test in terms of the item difficulty index.

When the discrimination indices of the items in the test in Table 2 are examined, it is seen that the values range between .35 and .74 . Below criteria can be used when interpreting the item discrimination values (Crocker and Algina, 1986, Tekin, 1996; Akt. Buyukozturk et al., 2013):

Table 3. Index of Discrimination

\begin{tabular}{|c|c|}
\hline Index of Discrimination of the Item & Assessment of the Item \\
\hline$\geq .40$ & Very good. \\
\hline Between 0.30 and 0.39 & $\begin{array}{r}\text { The item can be kept in the scale without making any } \\
\text { corrections. However, small changes can be made. A } \\
\text { good item. }\end{array}$ \\
\hline Between 0.20 and 0.29 & It is advised to develop the items by correcting. \\
\hline$<0.20$ & The item should be removed from the scale. \\
\hline
\end{tabular}

As is seen in Table 2, the average index of discrimination of the achievement test is 0.56 . This value is well above the value ( 0.40 and above) deemed as a very good item in Discrimination Index. According to this value, the test can be qualified as a good test.

\subsection{Data Analysis}

SPSS 21 package program was used in the analysis of the data. Data collected by means of the scale were analysed using the SPSS program and tabulated. During the analysis, the frequency, average, t-test in independent groups, ANOVA test, and Scheffe test to find the significant difference group were carried out.

\section{FINDINGS AND COMMENTS}

Findings on research results are as below.

Findings on the Achievement Test Scores of the Students on the Unit of the Adventure of the Democracy

The mean and standard deviation were calculated with the aim determining the levels of learning of the students in the unit of the Adventure of Democracy, and the results are shown in Table 4.

Table 4: Mean of the Scores of the Students on the Unit of the Adventure of Democracy

\begin{tabular}{cccccc}
\hline & Min. & Max. & $\bar{X}$ & ss. \\
\hline $\begin{array}{c}\text { Levels of } \\
\text { Acquisition }\end{array}$ & 22 & 2 & 25 & 13,03 & 5,62 \\
\hline
\end{tabular}


The lowest and highest scores that the students can get from the achievement test used in the research were shown in Table 4. Furthermore, as seen in the table, it is understood that the average score obtained by the academic achievement test of the Adventure of Democracy unit is $\bar{X}=13,03$. According to this finding, it is seen that the level of knowledge on the unit of the Adventure of Democracy of 122 students participating in the research is at intermediate level.

Findings on the Comparison of the Achievement Test Scores of the Students on the Unit of the Adventure of Democracy by Gender

T-test was conducted in independent groups in order to measure the effect of the gender factors on learning level in the unit of the Adventure of Democracy, and the results are shown in Table 5.

Table 5: T-Test Results of the Achievement Test Scores of the Students on the Unit of the Adventure of Democracy by Gender

\begin{tabular}{cccccc}
\hline Gender & N & $\bar{X}$ & ss & t & p. \\
\cline { 1 - 4 } Female & 63 & 12,67 & 5,43 & & \\
\cline { 1 - 4 } Male & 59 & 13,42 & 5,85 & & \\
\hline
\end{tabular}

As can also be understood from Table 5, the academic successes of both males $(\bar{X}=13,42)$ and females $(\bar{X}=12,67)$ are at intermediate level. According to t-test results, it was detected that the academic successes of males are higher when compared to those of the females $(t=-.741, p>.05)$, however there is no statistically significant difference between the genders.

Findings on the Comparison of the Achievement Test Scores of the Students on the Unit of the Adventure of Democracy in terms of Maternal Education Level

ANOVA test was carried out in order to measure the effect of the maternal education level on the level of acquisition of the Unit of the Adventure of Democracy, and the results are shown in Table 6.

Table 6: ANOVA Test Results by Maternal Education Level of the Achievement Test Scores of the Students with regard to the Unit of the Adventure of Democracy

\begin{tabular}{|c|c|c|c|c|c|}
\hline $\begin{array}{c}\text { Maternal Education } \\
\text { Level }\end{array}$ & $\mathbf{N}$ & $\bar{X}$ & $\mathbf{S S}$ & $\mathbf{F}$ & Sig (p.) \\
\hline Illiterate & 9 & 12.44 & 4.21 & & \\
\hline Primary school & 70 & 12,30 & 5,96 & \multirow{6}{*}{,940 } & \multirow{6}{*}{,444 } \\
\hline Secondary school & 30 & 14,37 & 4,98 & & \\
\hline High school & 10 & 14 & 3,71 & & \\
\hline University & 3 & 15,33 & 11,59 & & \\
\hline Master's & - & - & - & & \\
\hline Total & 122 & 13,03 & 5,62 & & \\
\hline
\end{tabular}


As is seen in Table 6, it was determined that there is no statistically significant difference in the fulfilment level of the acquisitions of the unit of the Adventure of Democracy by the education levels of the students, however, that the arithmetic mean of the students whose mothers are university graduates $(\bar{X}=15.33)$ is higher than all other options, and likewise, that the arithmetic mean of the students whose mothers are high school $(\bar{X}=$ 14.00) and secondary school $(\bar{X}=14,37)$ is higher than those whose mothers are primary school graduates or illiterate.

Findings on the Comparison of the Achievement Test Scores of the Students on the Unit of the Adventure of Democracy in terms of Paternal Education Level

ANOVA test was carried out in order to measure the effect of the paternal education level on the level of acquisition of the Unit of the Adventure of Democracy, and the results are shown in Table 7.

Table 7: ANOVA Test Results by Paternal Education Level of the Achievement Test Scores of the Students with regard to the Unit of the Adventure of Democracy

\begin{tabular}{cccccc}
\hline $\begin{array}{c}\text { Paternal Education } \\
\text { Level }\end{array}$ & $\mathbf{N}$ & $\bar{X}$ & ss & F & Sig (p.) \\
\hline Illiterate & 4 & 8,25 & 2,50 & & \\
\hline Primary school & 45 & 11,40 & 5,80 & & \\
\hline Secondary school & 33 & 13,03 & 5,22 & \multirow{2}{*}{3,885} & \multirow{2}{*}{, 005} \\
\cline { 1 - 4 } High school & 32 & 14,97 & 4,75 & & \\
\hline University & 8 & 16,88 & 6,64 & & \\
\hline Total & 122 & 13,03 & 5,62 & & \\
\hline
\end{tabular}

As is seen in Table 7, considering the level of fulfilment of the acquisitions of the unit of the Adventure of Democracy, it was determined that the education level of the father increases in direct proportion to the academic mean of the students (university $\bar{X}=16,88$, high school $\bar{X}=14,97$, secondary school $\bar{X}=13,03$, primary school $\bar{X}=11,40$, illiterate $\bar{X}=8,25)$. However, the increase in the scores of the academic successes of the students as the level of education of their father increases did not constitute a statistically significant difference.

Findings on the Comparison of the Achievement Test Scores of the Students on the Unit of the Adventure of Democracy by Settlements

T-test was carried out in independent groups in order to measure the effect of the settlement on the level of acquisition of the Unit of the Adventure of Democracy, and the results are shown in Table 8.

Table 8: T-Test Results by Settlement of the Achievement Test Scores of the Students with regard to the Unit of the Adventure of Democracy

\begin{tabular}{ccccccc}
\hline Settlement & & $\bar{X}$ & ss & t & p. \\
\cline { 1 - 4 } Village & 45 & 9,73 & 4,52 & & $-5,763$ & .000 \\
\cline { 1 - 4 } City & 77 & 14,96 & 5,33 & & \\
\hline \multicolumn{7}{c}{74}
\end{tabular}


When the fulfilment level of the acquisitions of the unit of the Adventure of Democracy is examined by the settlement, it was seen that the academic mean of the students living in the city is higher than the academic mean of the students living in the village ( $\bar{X}=$ $9,73)$, and a statistically significant difference $(p=, 000<0.05)$ is created in favour of the students living in the city.

\section{Findings on the Comparison of the Achievement Test Scores of the Students for the Unit of the Adventure of Democracy by Family Income}

ANOVA test was carried out in order to measure the effect of the family income level on the learning level in the unit of the Adventure of Democracy, and also Scheffe test was carried out in order to determine the group with a significant difference; and the results are given in Table 9.

Table 9: ANOVA Test Results of the Achievement Test Scores of the Students on the Unit of the Adventure of Democracy by Family Income

\begin{tabular}{|c|c|c|c|c|c|c|}
\hline $\begin{array}{c}\text { Income } \\
\text { Level of } \\
\text { the Family } \\
\end{array}$ & $\mathbf{N}$ & $\bar{X}$ & SS & $\mathbf{F}$ & Sig (p.) & $\begin{array}{l}\text { Significant } \\
\text { Difference }\end{array}$ \\
\hline $0-750$ & 62 & 11,02 & 4,91 & \multirow{5}{*}{8,046} & \multirow{5}{*}{,000 } & \multirow{5}{*}{$2-1,3-1,4-1$} \\
\hline $751-1500$ & 41 & 14,22 & 5,79 & & & \\
\hline $1501-2500$ & 11 & 15,91 & 3,20 & & & \\
\hline $\begin{array}{l}2500 \text { and } \\
\text { above }\end{array}$ & 8 & 18,63 & 6,09 & & & \\
\hline Total & 122 & 13,03 & 5,629 & & & \\
\hline
\end{tabular}

As can be understood from Table 9, when the fulfilment level of the acquisitions of the Unit of the Adventure of Democracy is examined, it is understood that the academic mean of the students increases in direct proportion with the income level of the family. According to the result of the ANOVA test carried out $(\mathrm{p}=.000<.05)$, it was seen that there is a statistically significant difference between the groups. With Scheffe test, it was determined that the academic successes of the students whose family income level is above 0-750 TL. is significantly higher than the student with an income that is lower than 0-750 TL.

\section{RESULTS AND DISCUSSION}

It was determined in the research that the level of learning of the students in the unit of the Adventure of Democracy of the 6th grade social studies lesson is at intermediate level. According to this result, it is understood that the knowledge of 6th grade students of Adiyaman province on the unit of the Adventure of Democracy is not fulfilled well. It is seen that this finding obtained from the study is similar to the finding of Oruç and Akgün (2010) that the level of acquiring the graphic reading skill of the students, one of the acquisitions of the 4 th grade social studies lesson, is close to the intermediate level $(47 \%)$ and the finding of Akgün (2013) that the level of fulfilment of the acquisitions of unit of "Adventure of Democracy" of the 8th Grade Citizenship and Democracy Education Lesson is at intermediate level according to the pre-test results.

In the analysis carried out in order to measure the effect of maternal education level on the education level in the unit of the Adventure of Democracy, it was seen that there is no 
statistically significant difference between the education level of the students' mothers and the fulfilment levels of the acquisitions. However, it is also seen that the arithmetic mean of the students whose mothers are university graduates is higher than all other options, and likewise, the arithmetic mean of the students whose mothers are high school and secondary school graduates is higher than the students whose mothers are primary school graduates or illiterate. The same applies to the paternal education level. The paternal education level increased in direct proportion to the academic mean of the students; however, the increase in the scores of the academic successes of the students as the level of education of their father increases did not constitute a statistically significant difference. That the academic successes of the students increased in direct proportion with the increase in the parents education level, although it is not statistically significant, can be explained with Kotaman's (2008) words that the rate of participation of the parents of the students into the education of the students differ by the level of education of the parents, the level of participation into education of the students whose parents are university graduates is higher than those whose parents are not university graduates, and in addition, there is a positive and statistically significant relationship between the participation of the parents and the academic success of their children. Gelbal (2008) put forth that the maternal education level does not have an effect on the level of success on its own, however it increases the student success in case the number of the siblings is low in addition to the high maternal education level. Yilmazer and Demir (2014) determined that the attitudes towards social studies lesson increase positively as the parental education level increases, however, this increase is not statistically significant. Kilincarslan (2008) stated that the education levels of the parents affect the school success of the students positively. In this sense, Keith et al. (1998) stated that the support from the parents to their children in the education process has a significant and great effect on the success of the students, and is among the direct factors affecting student success.

In the analysis carried out for the purpose of determining whether the acquisitions of the Adventure of Democracy Unit differ by the settlements of the students, it is seen that the academic success of the students living in the city is significantly higher than the academic success of the students living in the village. This result is similar to the finding of Oruç and Akgün (2010) that the level of gaining graphic preparation skills of the 7th grade students in city centre is significantly higher than those in the village school. Furthermore, it also overlaps with Coskun and Samanci's (2012) finding that the attitudes and social skills of the students studying in the schools in provincial or district centres towards social studies lesson are higher than those studying in the village.

As a result of the analysis carried out with the aim of determining whether the level of fulfilment of the acquisitions of the Adventure of Democracy Unit varies by the family income level, it was understood that the academic mean of the students increases in direct proportion with the income level of the family. It is seen that the academic means of the students whose family income level is $750 \mathrm{TL}$ and below are statistically significantly lower than the academic means of the students with a higher family income level. In this context, the amount that affects academic success by family income is whether the income is higher or lower than $750 \mathrm{TL}$, which is nearly equal to the minimum wage in Turkey. Starting from this result, it is seen that the academic success of the students in the Adventure of Democracy Unit increases as the family income level of the students increases. While this result overlaps with the findings of the study of Savas, Tas and Duru (2010), the reason for this result in the study in question was explained as the parents with a high income can provide better opportunities to their children, and this affects success positively; while families with a low income level have hardship in supplying the minimum school requirements of their children and children 
are set to work in various areas in order to contribute to the family budget, and this affects student success negatively. Gelbal (2008) states that families with a good economic situation can regulate the educational environments of their children and provide them different opportunities, and their power to provide their children any kind of academic support by paying close attention to their education problems and solving these problems on time may affect the academic successes of their children positively.

As a result of the analysis carried out with the aim of determining whether the level of fulfilment of the acquisitions of the Adventure of Democracy Unit varies by gender, it was found out that the academic successes of males are higher than females, however there is no statistically significant difference between the genders. This result is in parallel with the findings of Oruç and Akgün's (2010) and Akgün's (2013) studies. According to this result, it can be argued that the gender factor is not a significant variable in the Adventure of Democracy unit.

\section{SUGGESTIONS}

In the framework of the findings obtained as a result of the research process, below suggestions are made in order to gain the students the skills required in the unit of the "Adventure of Democracy" at the desired level.

More activities can be included in course and exercise books in order for the students to be able to acquire the skills provided for by the program. The content of the democracy subjects can be enriched, and the relationship between the acquisitions provided for by the program and the content can be reviewed. The parents can be given seminars by experts especially in the field of democracy, and the participation of the parents in these seminars can be promoted. In this study, it was determined that the academic successes of the students increase in direct proportion with the education level of the parents, although this is not statistically significant. The physical opportunities of village schools can be increased, and it can be ensured that their education environments are not behind the city schools. In this study, it was determined that the academic successes of the students studying in city schools are higher. Various events and education activities that fit the spirit of the structuralist philosophy can be held in order to gain the skills provided for by the social studies program to the students. Academic studies on why the skills provided for by the program do not actualize in the required level can be promoted.

\section{REFERENCES}

Akgün İ. H. (2013), Sekizinci Sinıf Vatandaşlık ve Demokrasi Ĕ̈itimi Dersinde Örnek Olay Yöntemiyle Öğretimin Öğrenme Düzeyine ve Kalıcllı̆̆a Etkisi. Ph. D. Thesis (Unpublished), Elazığ: Firat University.

Büyüköztürk Ş, Çakmak E, Akgün Ö.E, Karadeniz Ş. and Demirel, F. (2013), Bilimsel Araştırma Yöntemleri. Ankara: Pegem A Yayıncılık.

Coşkun N. and Samancı O. (2012), İlköğretim 4. ve 5. Sınıflarda Sosyal Beceri Düzeyi ile Sosyal Bilgiler Dersine Yönelik Tutumların Çeşitli Değişkenler Açısından Incelenmesi. Journal of Educational and Instructional Studies In the World, Vol. 2, Issue: 1, P. 32-41.

Flowers N. (2010), Pusulacık Çocuklar İçin İnsan Hakları Eğitimi Kılavuzu (Çev: Çulhaoğlu M.) İstanbul: Bilgi İletişim Grubu Yayıncılık. 
Gelbal S. (2008), The Effect of Socio-Economic Status of Eighth Grade Students On Their Achievement in Turkish. Education and Science, 2008, Vol. 33, P. 1-13.

Gündüz M. and Gündüz F. (2007), Yurttaşlık Bilinci. Ankara: Anı yayıncılık.

Karasar N. (2007), Bilimsel Araştırma Yöntemleri. Ankara: Nobel Yayın Dağıtım.

Keith T. Z, Keith, P. B, Kimberly J. Q, Sperduto J, Santillo S. \& Killings S. (1998), Longitudinal effects of parent involvement on high school grades: similarities and differences across gender and ethnic groups. Journal of School Psychology, 1998 Vol. 36, P. 335-362.

Kılınçarslan S. (2008), Ebeveynin Sosyoekonomik ve Kültürel Düzeyinin İlköğretim Öğrencilerinin Okul Başarllarına Etkileri ve Bir Uygulama. Master's Thesis (Unpublished), İstanbul: Beykent University.

Kotaman H, (2008), Türk Ana Babalarının Çocuklarının Eğitim Öğretimlerine Katılım Düzeyleri. Uludağ University Journal of the Faculty of Educatıon,, XXI (1): 135-149.

Oruç Ş. and Akgün İ. H. (2010), İlköğretim Sosyal Bilgiler 7. Sınıf Öğrencilerinin Grafik Okuma Becerisini Kazanma Düzeyleri, International Journal of Eurasia Social Sciences Volume:1, P. 51-58.

Parker W.C. (2009), Social Studies in Elemantary Education (Thirteenth Edition). The United States of America: Perason Education. Inc.

Savaş E., Taş, S., and Duru, A (2010), Factors Affecting Students' Achievement in Mathematics. Inonu University Journal of the Faculty of Education, April 2010/ Volume. 11, Issue. 1. pp. 113-132.

TDK (2009), Türkçe Sözlük. Ankara: Türk Dil Kurumu Yayınları.

TTK (2010), İlköğretim Vatandaşlık ve Demokrasi Ĕ̈itimi Dersi (Sekizinci Sınıf) Öğretim Programı. Ankara: Talim ve Terbiye Kurulu Başkanlığı Yayınları.

Uygun, O. (2003), Demokrasinin Tarihsel Felsefi ve Ahlaki Boyutları. İstanbul: İnkılap Kitabevi.

Yeşil, R. (2002), Okul ve Ailede Insan Hakları ve Demokrasi Ĕ̆itimi. Ankara: Nobel Yayın Dağıtım.

Yılmazer, A. and Demir S. B. (2014), Ortaokul Öğrencilerinin Sosyal Bilgiler Dersine ve Sosyal Bilgiler Öğretmenine Karşı Tutumları ile Akademik Başarıları Arasındaki İlişkinin İncelenmesi. Turkish Studies-International Periodical For The Languages, Literature and History of Turkish or Turkic, Volume 9/2 Winter 2014. pp. 1705-1718. 